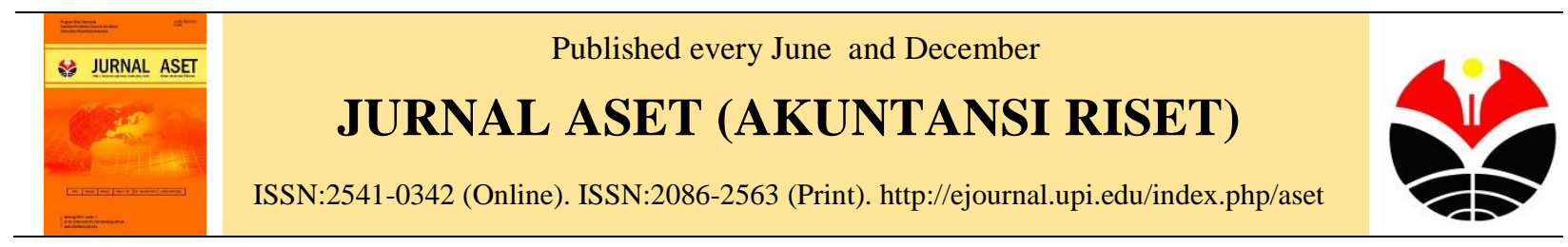

\title{
Pengaruh Penerapan Akuntansi Pertanggungjawaban Terhadap Pengendalian Biaya Pada Industri Manufaktur Di Batam
}

\author{
Adi Irawan Setiyanto ${ }^{1}$, Norafyana ${ }^{2}$ \\ Jurusan Manajemen Bisnis, Poiteknik Negeri Batam Jl. Ahmad Yani, Batam Centre, \\ Batam 29461, Indonesia \\ adiirawan@polibatam.ac.id ${ }^{1}$, norafyana68@gmail.com²
}

\begin{abstract}
Responsibility Accounting is part of Accounting Management that aims to collect and report accounting information for each responsibility center. This study aims to determine the effect of the application of responsibility accounting on cost control in the manufacturing industry and to test and to provide empirical evidence about the effect of the implementation of applied responsibility accounting. The result indicates that the organizational structure, budgeting, controlling and reporting in responsibility accounting simultaneously have positive effect on cost control. The limitation of the study is that the sample used is only in the food manufacturing industry and the study also uses only questionnaires without interview. For further study, it is suggested that the researchers should add more variables, involve broader samples and participants, and also interview the participants so the conclusion stated is not only based on data collected by written instruments, but also based on the research directly.
\end{abstract}

Keywords: Responsibility Accounting, Cost Control

Abstrak. Akuntansi pertanggungjawaban merupakan bagian dari akuntansi manajemen yang bertujuan mengumpulkan serta melaporkan informasi akuntansi untuk masing-masing pusat pertanggungjawaban. Penelitian ini bertujuan untuk mengetahui pengaruh penerapan akuntansi pertanggungjawaban terhadap pengendalian biaya di perusahaan industri manufaktur dan untuk menguji dan memberikan bukti empiris mengenai pengaruh pelaksanaan akuntansi pertangungjawaban yang diterapkan. Hasil penelitian ini menunjukan bahwa struktur organisasi, anggaran, pengendalian dan pelaporan didalam akuntansi pertanggungjawaban secara simultan berpengaruh positif terhadap pengendalian biaya. Keterbatasan pada penelitian ini adalah sampel yang digunakan hanya pada industri manufaktur dibidang makanan dan penelitian ini hanya menggunakan kuesioner tidak disertai dengan wawancara langsung. Saran untuk penelitian selanjutnya sebaiknya peneliti menambahkan variabel penelitian, perluasan sampel dan responden serta mengunakan metode wawancara sehingga kesimpulan yang di kemukakan tidak hanya berdasarkan data yang terkumpul melalui instrument secara tertulis namun penelitian secara langsung.

Kata Kunci: Akuntansi Pertanggungjawaban, Pengendalian Biaya

Corresponding Author. J1. Ahmad Yani, Batam Centre, Batam 29461, Indonesia

How to Cite This Article. Irawan, Norafyana. Pengaruh Penerapan Akuntansi Pertanggungjawaban Terhadap Pengendalian Biaya Pada Industri Manufaktur Di Batam. Jurnal Akuntansi Riset.. Program Studi Akuntansi. Fakultas Pendidikan Ekonomi dan Bisnis Universitas Pendidikan Indonesia, 9(1), 45-54 History of article. Received : 21-11-2016, Revision: 08-12-2016, Published: 14-02-2017 


\section{PENDAHULUAN}

Era globalisasi mempunyai dampak dalam dunia ekonomi. Saat ini, persaingan yang terjadi dalam dunia ekonomi sudah semakin ketat diantara perusahaan-perusahaan untuk mendapatkan pangsa pasar yang dibidiknya. Dengan adanya globalisasi maka dunia usaha mau tidak mau didorong untuk mencapai suatu organisasi yang efektif dan efisien. Perusahaan harus mulai mengelola kegiatan operasionalnya, memperbaiki proses bisnis dan mempersiapkan secara matang agar perusahaan memperoleh keungulan kompetitif sebagai upaya perusahaan untuk mencapai tujuan yang telah ditetapkan, serta agar dapat bersaing dengan perusahaan lainnya, baik domestik maupun internasional (Taufan, 2010), agar dapat terus bertahan dan bersaing dalam dunia ekonomi yang semakin kompetitif, strategi management mutlak sangat dibutuhkan. Management berupaya untuk meningkatkan kinerja dan melakukan pengendalian terhadap biaya-biaya yang akan dikeluarkan agar tujuan perusahaan dapat berjalan sebagai mana diharapkan. Untuk mengatasi masalah tersebut diperlukan suatu sistem pengendalian management di dalam perusahaan.

Menurut Supriyono (2000) sistem pengendalian manajemen terdiri atas dua unsur, yaitu: struktur pengendalian manajemen yang terdiri dari pusat-pusat pertanggungjawaban dan proses pengendalian manajemen yang membahas cara kerjanya pusat-pusat pertanggungjawaban dengan menggunakan informasi yang ada. Akuntansi pertanggungjawaban merupakan bagian dari akuntansi manajemen yang bertujuan mengumpulkan serta melaporkan informasi akuntansi untuk masingmasing pusat pertanggungjawaban, baik berupa rencana maupun yang sudah terealisasi.

Akuntansi pertanggungjawaban juga perlu dievaluasi agar berlangsung dengan baik sehingga manajemen dapat dengan mudah menghubungkan biaya yang timbul dengan manajer pusat pertanggungjawaban yang bertanggung jawab. Penerapan akuntansi pertanggungjawaban yang memadai mampu mendorong perusahaan guna mencapai tujuan perusahaan.

Perusahaan manufaktur menuntut kesiapan management perusahaan dalam pengendalian biaya, hal ini dikarenakan tingkat pertumbuhan dan persaingan dunia bisnis saat ini mengharuskan perusahaan untuk memandang jauh ke depan guna mengantisipasi berbagai kemungkinan yang dapat mempengaruhi perkembangan perusahaannya. Efisiensi pengendalian biaya perusahaan merupakan salah satu cara perusahaan dalam meningkatkan laba.

\section{KAJIAN LITERATUR Kaizen Theory}

Kaizen adalah suatu filosofi dari Jepang yang memfokuskan diri pada pengembangan dan penyempurnaan secara terus menerus atau berkesinambungan dalam perusahaan bisnis. Dalam bahasa Jepang, kaizen berarti perbaikan berkesinambungan (Imai, 1999). Istilah ini mencakup pengertian perbaikan yang melibatkan semua orang baik manajer dan karyawan dan melibatkan biaya dalam jumlah tak seberapa. Filosof dari kaizen adalah melaksanakan perbaikan atau peningkatan yang berkesinambungan. Format kaizen dapat berupa perseorangan sistem saran, kelompok kecil, atau kelompok besar, sampai bawahan atau istilahnya way of life perusahaan. Teori Kaizen dalam penelitian ini menjadi dasar untuk 
melakukan perbaikan dalam perusahaan salah satunya melaui akuntansi pertanggungjawaban.

\section{Akuntansi Pertanggungjawaban}

Hansen \& Mowen (2005) mendefinisikan akuntansi pertanggungjawaban sebagai suatu sistem yang mengukur berbagai hasil yang dicapai oleh setiap pusat pertanggungjawaban menurut informasi yang dibutuhkan oleh para manajer untuk mengoperasikan pusat pertanggungjawaban mereka. Akuntansi pertanggungjawaban memiliki empat elemen penting yaitu pembebanan tanggung jawab, pembuatan ukuran kinerja atau benchmarking, pengevaluasian kinerja dan pemberian penghargaan (Hansen \& Mowen, 2012). Akuntansi pertangungjawaban menurut Anthony \& Hermanson (2001) memiliki tujuan yaitu membebani pusat pertangungjawaban dengan biaya yang dikeluarkanya. Menurut Mulyadi (2001) terdapat empat syarat dapat diterapkannya sistem akuntansi pertangungjawaban, diantaranya yaitu struktur organisasi, anggaran, sistem akuntansi, dan sistem pelaporan biaya.

\section{Pengendalian Biaya}

Pengendalian biaya adalah
tindakan yang dilakukan untuk
mengarahkan aktivitas agar tidak
menyimpang dengan tujuan yang telah
ditetapkan sebelumnya. Pengendalian
biaya ini dapat dilakukan melalui
anggaran biaya yang secara kontinu
diadakan pengawasan secara analisis
terhadap penyimpangan yang terjadi
sehingga dapat diketahui penyebab
terjadinya penyimpangan atas selisih
tersebut kemudian dilakukan tindak
lanjut agar kerugian yang terjadi relatif
kecil (Trisnawati, 2006).
Penelitian mengenai pengaruh
penerapan akuntansi

pertanggungjawaban terhadap efektifitas pengendalian biaya oleh Ardiani \& Wirasedana (2013) menyimpulkan bahwa penerapan akuntansi pertanggungjawaban memberikan pengaruh yang positif dan signifikan terhadap efektivitas pengendalian biaya. Angela (2009) yang meneliti tentang penerapan akuntansi pertanggungjawaban sebagai alat pengendalian biaya pada PT. XYZ Makassar, menemukan bahwa belum adanya pemisahan biaya antara biaya terkendali dan biaya tidak terkendali yang disebabkan oleh karena perusahaan belum merealisasikan laporan pertanggungjawaban biaya bagi setiap pusat pertanggungjawaban serta belum adanya penjelasan tentang penyebab terjadinya selisih antara biaya yang dianggarkan dengan realisasi biaya tersebut. Kesimpulan dari penelitian ini adalah belum efektifnya penerapan akuntansi pertanggungjawaban pada perusahaan tersebut.

Dari beberapa hasil penelitian terdahulu menyatakan bahwa belum semua perusahaan yang telah menerapkan akuntansi pertangungjawaban sebagai alat pengendalian biaya maupun penilaian kinerja manajemennya, telah mencapai hasil yang lebih efektif, dan dari beberapa hasil penelitian terdahulu menggunakan metode deskriptif komparatif dengan cara membandingkan anggaran dan realisasinya yang ada dalam laporan pertanggungjawaban, kemudian dianalisis apa yang menyebabkan terjadinya varians antara anggaran yang telah ditetapkan dengan realisasinya. Sedangkan dalam penelitian ini, metode yang digunakan adalah metode kuantitatif dengan menggunakan kuesioner, dan dari hasil kuesioner tersebut akan diolah lebih lanjut untuk mengetahui bagaimana penerapan 
akuntansi pertanggungjawaban yang dilakukan oleh perusahaan.

\section{METODOLOGI PENELITIAN}

Populasi penelitian ini adalah perusahaan manufaktur bidang makanan yang terdaftar di Badan Pusat Statistik Kota Batam tahun 2015. Teknik penarikan sampel yang digunakan adalah cluster sampling atau sampling area. Penentuan perusahaan mana yang akan dijadikan sampel ditetapkan secara random, dan menentukan jumlah sampel yang digunakan pada masingmasing daerah tersebut dengan menggunakan teknik porposive sampling dengan kriteria judgment sampling. Alat pengambilan data yaitu berupa kuesioner.

\section{Karakteristik sampel penelitian}

Responden dalam penelitian ini adalah karyawan yang bekerja pada kelompok perusahaan Industri Manufaktur. Terdapat 5 karakteristik responden yang dimasukkan dalam penelitian, yaitu berdasarkan jenis kelamin, latar belakang pendidikan, pendidikan terakhir, jabatan dan lama bekerja.

\section{Metode Analisis}

Variabel-variabel yang diteliti dalam penelitian ini adalah pengendalian biaya sebagai variabel dependen, Akuntansi pertanggungjawaban sebagai variabel independen. Metode analisis data yang digunakan dalam penelitian ini adalah regresi berganda

$$
\underset{\beta 4 X 4+e}{Y=a+\beta 1 X 1+\beta 2 X 2+\beta 3 X 3+}
$$

Keterangan :

$\mathrm{Y}=$ Efisiensi biaya

$A=$ Nilai intercept (konstanta)

$\beta=$ Koefisien regresi

$\mathrm{X} 1=$ Nilai yang ditentukan untuk struktur organisasi

\author{
$\mathrm{X} 2=$ Nilai yang ditentukan \\ untuk perencanaan/anggaran \\ X3= Nilai yang ditentukan \\ untuk pelaksanaan/pengendalian \\ X4 = Nilai yang ditentukan \\ untuk akuntabilitas
}

\section{Hipotesis \\ Pengaruh Akuntansi \\ Pertanggungjawaban terhadap Pengendalian Biaya}

Akuntansi pertanggungjawaban merupakan bagian dari akuntansi manajemen yang bertujuan mengumpulkan serta melaporkan informasi akuntansi untuk masingmasing pusat pertanggungjawaban, baik berupa rencana maupun yang sudah terealisasi.

Akuntansi pertangungjawaban dalam penerapannya memerlukan struktur organisasi, penyusunan anggaran, pengendalian dan pelaporan sesuai dengan apa yang dibutuhkan dan realisasinya sesuai dengan biaya yang telah disediakan. Manager perusahaan perlu memiliki keahlian dalam efisiensi pengendalian biaya didalam perusahaan sebagai upaya peningkatan laba dan pencapaian tujuan perusahaan.

Mulyadi (2001) memaparkan bahwa akuntansi pertanggungjawaban memiliki syarat-syarat yang harus dipenuhi, yaitu: struktur organisasi yang menetapkan secara tegas wewenang dan tanggung jawab tiap tingkatan manajemen; anggaran biaya yang disusun untuk tiap tingkatan manajemen; penggolongan biaya sesuai dengan dapat atau tidaknya biaya tersebut dikendalikan (controllability) oleh manajemen tertentu dalam operasi; terdapatnya susunan kode rekening perusahaan yang dikaitkan dengan kewenangan pengendalian pusat pertanggungjawaban, dan sistem pelaporan biaya kepada manajer yang bertanggung jawab. 
Perusahaan dengan pengendalian biaya yang baik diharapkan dapat terus berkembang dan bersaing dengan perusahaan lainnya, domestik maupun internasional.

Akuntansi pertangungjawaban tidak dapat dipisahkan dari tujuan yang diharapkan perusahaan.

Penelitian terdahulu yang dilakukan oleh Moses et al. (2012) mengemukakan bahwa keterlibatan manager dalam penyusunan anggaran dan kerjasama yang terjalin dalam pusat pertanggungjawaban mempengaruhi keefektivitasan pengendalian biaya dalam perusahaan. Penelitian mengenai hubungan antara penerapan akuntansi pertanggungjawaban dengan efektivitas pengendalian biaya yang dilakukan oleh Hutabarat (2009) dengan hasil yang menunjukan bahwa terdapat hubungan positif antara akuntansi pertanggungjawaban dengan efektivitas pengendalian biaya.

Penelitian Apriyanti (2000) menunjukan hasil bahwa terdapat hubungan positif antara penerapan akuntansi pertanggungjawaban dengan efektivitas pengendalian biaya. Selain itu, hasil penelitian yang dilakukan oleh Wahyuni (2012) dengan mengunakan metode observasi non partisipan dan metode kuesioner, menunjukan bahwa terdapat hubungan antara penerapan akuntansi pertanggungjawaban terhadap efektivitas pengendalian biaya.

Penelitian yang dilakukan oleh Martusa (2010) tentang Evaluasi Biaya Standar Dalam Pengendalian Biaya Produksi (Studi kasus pada PT. PG. Rajawali, Subang). Kesimpulan dalam penelitian ini adalah penetapan biaya produksi standar pada PT PG Rajawali telah memadai, dapat dilihat dari perusahaan telah menetapkan sistem biaya standar ke dalam proses produksi. Biaya yang diterapkan oleh perusahaan telah berperan dalam pengendalian biaya produksi, terbukti dengan adanya pencapaian tujuan pengendalian.

Berdasarkan penjelasan sebelumnya maka penulis mengajukan hipotesis :

H1. Struktur organisasi, perencanaan atau anggaran, pelaksanaan atau pengendalian dan pelaporan dalam akuntansi pertangungjawaban bersama-sama berpengaruh positif terhadap pengendalian biaya.

\section{HASIL DAN PEMBAHASAN}

\section{Hasil Penelitian}

Data yang digunakan dalam penelitian ini yaitu perusahaan manufaktur bidang makanan yang terdaftar di Badan Pusat Statistik selama periode 2015 yaitu berjumlah 894 perusahaan dengan presentase $5 \%$ sebagai karyawan middle management sehingga sampel yang didapatkan berdasarkan perhitungan rumus Slovin adalah 41 responden. 
1. Statistik Deskriptif

Tabel 4.1

Karakteristik Sampel

\begin{tabular}{|c|c|c|c|c|}
\hline No & Informasi Umum & Item & Frekuensi & $\begin{array}{l}\text { Prosentase } \\
(\%)\end{array}$ \\
\hline \multirow[t]{2}{*}{1} & \multirow[t]{2}{*}{ Jenis Kelamin } & Laki-Laki & 19 & $46.3 \%$ \\
\hline & & Perempuan & 22 & $53.7 \%$ \\
\hline \multirow[t]{5}{*}{2} & \multirow{5}{*}{$\begin{array}{l}\text { Latar Belakang } \\
\text { Pendidikan }\end{array}$} & Ekonomi/Akuntansi & 27 & $65.9 \%$ \\
\hline & & Teknik & 2 & $4.9 \%$ \\
\hline & & Hukum & 6 & $14.6 \%$ \\
\hline & & Sosial & 1 & $2.4 \%$ \\
\hline & & Lainnya & 5 & $12.2 \%$ \\
\hline \multirow[t]{3}{*}{3} & \multirow{3}{*}{$\begin{array}{l}\text { Pendidikan } \\
\text { Terakhir }\end{array}$} & SLTA/Sederajat & 15 & $36.6 \%$ \\
\hline & & Diploma & 14 & $34.1 \%$ \\
\hline & & Strata 1 (Sarjana) & 12 & $29.3 \%$ \\
\hline \multirow[t]{3}{*}{4} & \multirow[t]{3}{*}{ Jabatan } & Kepala Devisi & 20 & $48.8 \%$ \\
\hline & & Sekretaris & 7 & $34.1 \%$ \\
\hline & & Lainnya & 14 & $17.1 \%$ \\
\hline \multirow[t]{4}{*}{5} & \multirow[t]{4}{*}{ Lama Bekerja } & $1-5$ tahun & 16 & $39.0 \%$ \\
\hline & & $6-10$ tahun & 12 & $29.3 \%$ \\
\hline & & 11-15 tahun & 6 & $14.6 \%$ \\
\hline & & 16-20 tahun & 7 & $17.1 \%$ \\
\hline
\end{tabular}

Sumber: data mentah diolah

\subsubsection{Pengujian Hipotesis}

\begin{tabular}{crrrrr}
\hline \multicolumn{7}{c}{ ANOVA $^{\text {a }}$} \\
\hline Model & Sum of & & & & \\
\hline Regression & Squares & \multicolumn{1}{c}{ Df } & Mean Square & \multicolumn{1}{c}{ F } & \multicolumn{1}{c}{ Sig. } \\
Residual & 1192.27 & 4 & 298.068 & 59.7 & $.000^{\text {b }}$ \\
\hline Total & 179.482 & 36 & 4.986 & & \\
\hline
\end{tabular}

Tabel 4.2 Hasil uji signifikansi regresi berganda dengan uji F (Anova) Sumber: data mentah diolah menggunakan software SPSS 
Berdasarkan hasil analisis regresi linier berganda dengan menggunakan uji F(ANOVA) antara penerapan struktur organisasi, sistem perencanaan atau anggaran, sistem pelaksanaan atau pengendalian, dan sistem pelaporan didalam akuntansi pertanggungjawaban terhadap pengendalian biaya berdasarkan hasil output SPSS pada Tabel 4.6 terlihat bahwa nilai $\mathrm{F}$ hitung adalah 59.786 dengan tingkat tingkat signifikansi sebesar $0.000<0.05$, nilai $F$ tabel sebesar 4.09. Hasil ini menunjukkan bahwa $\mathrm{F}$ hitung lebih besar daripada $\mathrm{F}$ tabel, maka dapat disimpulkan bahwa $\mathrm{H} 1$ diterima, ini berarti secara bersama-sama variabel akuntansi pertanggungjawaban secara signifikan mempengaruhi pengendalian biaya.

Setelah dilakukan pengujian dan berdasarkan hasil output dari SPSS

Tabel 4.3

Hasil uji signifikansi regresi berganda dengan Uji Sig

Coefficients $^{\mathrm{a}}$ terbukti bahwa akuntansi pertanggungjawaban secara bersamasama mempengaruhi pengendalian biaya. Akan tetapi melalui hasil uji regresi linear berganda terdapat dua variabel didalam akuntansi pertanggungjawaban yang tidak mempengaruhi pengendalian biaya diantaranya variabel struktur ogranisasi dan pelaporan sedangkan variabel perencanaan dan pelaksanaan secara signifikan mempengaruhi pengendalian biaya. Hal tersebut dikarenakan masih kurangnya penerapan struktur organisasi yang baik didalam perusahaan industri manufaktur serta kurangnya pengawasan pelaporan biaya didalam perusahaan.

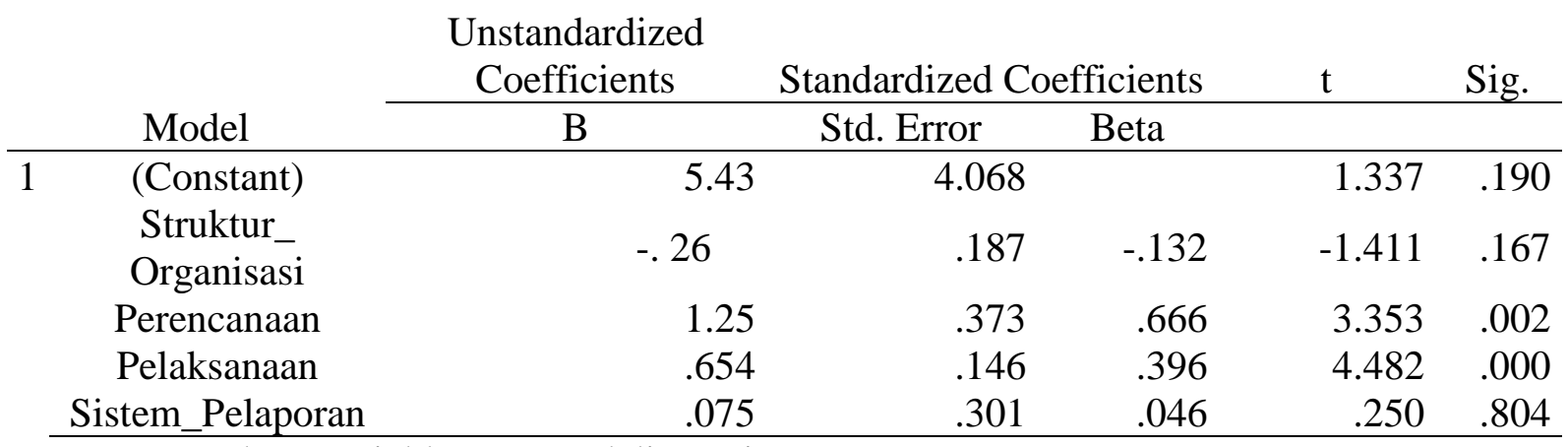

a. Dependent Variable: Pengendalian_Biaya

Sumber: data mentah diolah menggunakan software SPSS 


\section{SIMPULAN}

\section{Simpulan}

Berdasarkan hasil analisis dan pembahasan tentang pengaruh penerapan struktur organgisasi, perencanaan atau anggaran sistem pelaksanaan atau pengendalian, dan sistem pelaporan dalam akuntansi pertanggungjawaban terhadap pengandalian biaya pada industri manufaktur di batam, maka dapat ditarik kesimpulan sebagai berikut. Terdapat pengaruh yang positif dan signifikan antara variabel akuntansi pertanggungjawaban terhadap pengendalian biaya. Sehingga dengan adanya akuntansi pertanggungjawaban yang tinggi akan membuat pengendalian biaya menjadi tinggi pula.

\section{Implikasi}

Implikasi pada penelitian ini ditujukan kepada perusahaan industri manufaktur. Perusahaan industri manufaktur harus lebih memperbaiki internal perusahaan dalam hal struktur organisasi dan pertanggungjawaban pelaporan biaya agar akuntansi pertanggungjawaban di dalam perusahaan berjalan dengan baik dan perusahaan dapat meningkatkan kualitas perusahaan ketingkat internasional.

\section{Keterbatasan}

Keterbatasan dalam penelitian ini yaitu penelitian ini hanya menggunakan metode kuesioner tanpa melakukan wawancara secara langsung dalam aktivitas perusahaan, sehingga kesimpulan yang di kemukakan hanya berdasarkan data yang terkumpul melalui instrument secara tertulis. Penelitian ini hanya dilakukan pada perusahaan manufaktur yang bergerak dalam industri makanan. Responden pada penelitian ini sebagian besar adalah kepala devisi atau middle management yang memungkinkan pengisian kuesioner bersifat tidak objektif.

\section{DAFTAR PUSTAKA}

Angela, N. G. (2009). Penerapan Akuntansi

Pertanggungjawaban Sebagai Alat Pengendalian Biaya dan Penilaian Kinerja pada PT. XYZ Makasar. Skripsi Akuntansi Universitas Hasanudin Makasar.

Apriyanti, D. (2000). Hubungan Antara Penerapan Akuntansi Pertanggungjawaban dengan Efektivitas Pengendalian Biaya. Skripsi.

Ardiani, N. M., \& Wirasedana, I. W. (2013). Pengaruh Penerapan Akuntansi

Pertanggungjawaban Terhadap Efektivitas Pengendalian Biaya. E-Jurnal Akuntansi Universitas Udayana, 561-573.

Hansen, D. R., \& Mowen, M. (2005). Akuntansi Managemen. Jakarta: Salemba Empat.

Hansen, D. R., \& Mowen, M. (2012). Akuntansi Management. Jakarta: Salemba Empat.

Hutabarat, G. (2009). Hubungan Penerapan Akuntansi Pertangungjawaban dengan Efektivitas Pengendalian Biaya. Jurnal Ilmiah Satya Nugraha Indonesia.

Imai, M. (1999). Gemba Kaizen, Seri Management Operasi No.2 (Terjemahan). Jakarta: PPM Dan Yayasan Toyota Astra. 
Martusa, R. (2010). Evaluasi Biaya Standar Dalam Pengendalian Biaya Produksi (Studi kasus pada PT. PG. Rajawali, Subang). Jurnal Bisnis, Management \& Ekonomi.

Moses, N., Gumisai, J. G., Silibaziso, Z., Frank, T., \& Clainos, C. (2012). An Analysis of Efective Responbility Accounting System Strategies in the Zimbabwean Healt Sector. Journal Finance and Accounting, 86-92.

Mulyadi. (2001). Akuntansi Management. Jakarta: Salemba Empat.

Supriyono, R. (2000). Sistem Pengendalian Management. Vol. Buku 1.

Trisnawati, S. (2006). Hubungan antara Penerapan Akuntansi Pertanggungjawaban dengan Efektivitas Pengendalian Biaya: Survei pada 5 Hotel di Kota Tasikmalaya. Skripsi, Universitas Islam Indonesia, Yogyakarta.

Wahyuni, D. A. (2012). Hubungan Penerapan Akuntansi Pertanggungjawaban dengan Efektivitas Pengendalian Biaya di Inna Hotel Group Bali. Skripsi. 
ADI IRAWAN SETIYANTO , NORAFYANA/ Pengaruh Penerapan Akuntansi Pertanggungjawaban Terhadap Pengendalian Biaya Pada Industri Manufaktur Di Batam 